\title{
Peningkatan Hasil Belajar Matematika Melalui Strategi Pembelajaran Kreatif-Produktif Pada Materi Operasi Aljabar
}

\author{
${ }^{1}$ Ayu Komalasari, ${ }^{2}$ Darmasih \\ ${ }^{1}$ GuruMatematika, SMAN 2 Lambu Bima, Indonesia, ayu.k@gmail.com \\ ${ }^{2}$ Guru Matematika, MA Ittihadul Umam, Indonesia, damaradara@gmail.com
}

\begin{tabular}{l}
\hline \hline INFO ARTIKEL \\
RiwayatArtikel: \\
Diterima: $17-02-2019$ \\
Disetujui: $30-04-2019$ \\
\\
\hline
\end{tabular}

Kata Kunci:

Hasil Belajar, KreatifProduktif, dan Operasi Aljabar

\section{Keywords:}

Learning Outcomes, creative-productive, algebraic operating

\begin{abstract}
ABSTRAK
Abstrak: Tujuan penelitian ini adalah untuk meningkatkan hasil belajar matematika siswa kelas VIII SMP melalui penerapan strategi pembelajaran kreatif-produktif. Jenis penelitian ini adalah penelitian tindakan kelas (PTK). Data yang dikumpulkan dari penelitian adalah hasil tes dan observasi. Hasil penelitian menunjukkan bahwa nilai rata-rata diperoleh siswa pada siklus I sebesar 48,68 dengan ketuntasan klasikal belajar sebsar 71,42 dan pada siklus II nilai rata-rata sebesar 64,34 dengan ketuntasan klasikal belajar sebsar $78,12 \%$. Sedangkan aktivitas siswa pada siklus I pertemuan pertama menghasilkan rata-rata 8,4 dan pertemuan kedua dengan rata-rata sebesar 10,2, kemudian pada siklus II pertemuan pertama dengan rata-rata 11,6 dan pada pertemuan kedua dengan rata-rata 15,4. Hasil penelitian menujukkan adanya peningkatan hasil belajar matematika melalui strategi pembelajaran kreatif-produktif pada materi operasi aljabar kelas VIII SMP.

Abstract:The purpose of this study was to improve the mathematics learning outcomes of eighth grade students of Junior High School through the application of creative-productive learning strategies. This type of research is classroom action research (CAR). Data collected from research are test results and observations. The results showed that the average value obtained by students in the first cycle was 48.68 with the classical completeness of learning was 71.42 and in the second cycle the average score was 64.34 with the classical completeness of learning was $78.12 \%$. While the activities of students in the first cycle of the first meeting produced an average of 8.4 and the second meeting with an average of 10.2, then in the second cycle the first meeting with an average of 11.6 and at the second meeting with an average of 15, 4. The results of the study showed an increase in mathematics learning outcomes through creative-productive learning strategies in algebraic operating material in eighth grade students of Junior High School.
\end{abstract}

\section{A. LATAR BELAKANG}

Keberhasilan pelaksanaan pembelajaran disatuan pendidikan dapat terlihat dikualitas pembelajaran yang dihasilkan. Kegiatan pembelajaran akan dapat berjalan secara optimal apabila semua komponen dalam indikator kualitas pembelajaran berjalan dengan baik, termasuk didalamnya keterampilan guru dan aktivitas siswa (Hasibuan dan Moedjino,2009).

Matematika sebagai salah satu ilmu dasar, memiliki nilai esensial dalam kehidupan sehari-hari. Pemahaman tentang matematika juga dapat dijadikan suatu landasan penguasaan ilmu dan terknologi. Namun hingga saat ini mata pelajaran matematika masih dianggap sebagai mata pelajaran menakutkan, sulit, dan membosankan. Fenomena ini bukan rahasia umum lagi, tetapi banyak terjadi di setiap lembaga pendidikan mulai dari SD hingga SMA
(Faizi,2013:5). Dalam hal ini guru mendapatkan peran sekaligus tanggung jawab penting dalam mengembangkan pembelajaran yang tepat, yang bisa membantu para siswa memahami matematika secara lebih mudah dan menyenangkan. Hasil observasi yang dilakukan di kelas VIII SMP Negeri 1 Lambu menunjukkan hal yang berbeda dengan teori keberhasilan dan kegiatan belajar di atas, kegiatan pembelajaran yang dilakukan masih belum optimal. Hal ini dikarenakan kurangnya pemanfaatan media dan metode pembelajaran yang belum bervariasi dari guru. Guru masih belum meksimal dalam memanfaatkan media pembelajaran yang ada disekitar lingkungan siswa seperti penggunaan peta, globe dan gambar-gambar. Dalam kegiatan pembelajaran, hanya metode ceramah dan tanya jawab saja yang paling dominan terlihat. Siswa menjawab jika guru terlebih dahulu yang harus bertanya. Selain itu, guru belum memotivasi siswa 
dalam mengikuti proses pembelajaran matematika akibatnya minat siswa terhadap pembelajaran matematika menjadi kurang maksimal. Kemudian siswa kurang berpartisipasi aktif dalam pembelajaran dan siswa merasa bosan. Hal ini dibuktikan dengan rata-rata ketuntasan klasikal belajar siswa hanya mencapai $63,25 \%$. Tentu hal ini menjadi kewajiban bagi guru untuk menuntaskan permasalahan tersebut sehingga hasil belajar siswa meningkat. Salah satu metode terbaik yang harus digunakan oleh guru untuk permasalahan ini adalah menerapkan metode pembelajaran kreatif produktif.

\section{B. METODE PENELITIAN \\ 1. Jenis Penelitian}

Penelitian ini adalah Penelitian Tindakan Kelas (Classroom Action Research). Penelitian tindakan kelas yang dinama seorang peneliti terlihat aktif dalam tindakan pemesahan masalah (Dimyati dan mudjono, 2000:10) kemudian adapun yang menjadi ciri-ciri PTK antara lain: (1)merupakan kegiatan nyata untuk meningkatkan kualitas proses belajar mengajar, (2) merupakan tindakan oleeh guru kepada siswa, (3) tindakan harus berbeda dari kegiatan biasanya, (4) terjadi dalam siklus berkesinambungan, minimum tiga siklus,(5) ada pedoman yang jelas secara tertulis bagi siswa untuk dapat mengikuti tahap demi tahap, (6) ada untuk kerja siswa sesuai pedoman tertulis dari guru, (7) ada penelusuran terhadap proses dengan berdasar pedoman pengamatan,(8) dan evaluasi terhadap hasil penelitian dengan instrumen yang relevan, (9) keberhasilan tindakan dilakukan dalam bentuk refleksi dan melibatkan siswa yang di kenai tindakan, dan (10) hasil reflesi harus terlihat dalam perencanaan siklus berikutnya.

Penelitian tindakan kelas adalah suatu pencermatan terhadap kegiatan belajar berupa sebuah tindakan, yang sengaja dimunculkan dan terjadi dalam sebuah kelas secara bersama (Arikunto, 2008:2). Metode penelitian tindakan kelas ini menekankan pada suatu kajian yang benar-benar dari situasi alamiah kelas sehingga mampu memperbaiki dan meningkatkan kualitas belajar mengajar. Pelaksanaan ini berupa pemberian tindakan terhadap perilaku siswa dalam rangka optimalisasi. Optimalisasi pembelajaran yang dimaksud adalah memperbaiki perilaku pembelajaran yang kurang pada siswa, menjadi baik, serta yang baik menjadi lebih baik, sehingga tujuan pembelajaran dapat obtimal dan berhasil siswa agar lebih meningkat.

\section{Pendekataan Penelitian}

Pendekatan penelitian yang digunakan dalam penelitian ini adalah pendekatan kualitatif dan pendekatan kuantitatif. Pendekatan kualitatif adalah pendekatan memperoleh data dalam bentuk kata, kalimat atau gambar sedangkan pendekatan kuantitatif adalah pendekatan yang diperoleh berbentuk angka (Sugiyono, 2013: 9). Pendekatan kuantitatif digunakan untuk mengolah data hasil obervasi pelaksanaan pembelajaran

\section{Prosedur penelitian}

Penelitian tindakan kelas (PTK) yang dimaksud dirancang 2 siklus. Setiap siklus terdiri dari 4 tahap yaitu perencanaan, pelaksanaan tindakan, observasi dan evaluasi atau refleksi. Skema penelitian kelas tersebut dapat dilihat seperti gambar 3.1 dibawah ini.

\section{Instrumen Penelitian Dan Teknik \\ Pengumpulan Data}

Instrumen penelitian adalah alat atau fasilitas yang digunakan oleh peneliti dalam mengumpulkan data agar pekerjaannya lebih mudah dan hasilnya lebih baik, dalam arti lebih cermat, lengkap dan sistematis sehingga lebih mudah diolah (Arikunto, 2006:160).

Adapun instrumen yang digunakan oleh peneliti dalam penelitian ini adalah:

a. Lembar observasi aktivitas guru dan siswa

Merupakan instrumen penelitian yang digunakan untuk mengetahui aktivitas guru dan siswa pada saat proses pembelajaran sedang berlangsung. Pengamat menulis nomor-nomor kategori yang dominan muncul pada lembar pengamatan.Kategori pengamatan aktivitas guru adalah sebagai berikut:

1) Membangkitkan minat dan motivasi

2) Memberikan apersepsi

3) Menyampaikan materi

4) Mengatur waktu dan kegiatan secara kelompok dan melihat situasi

5) Mendampingi siswa selama proses belajar berlangsung

6) Mengakhiri pembelajaran.

Sedangkan kategori pengamatan aktivitas siswa adalah sebagai berikut:

1) Antusias siswa dalam pembelajaran

2) Respon siswa dalam pembelajaran

3) Aktivitas siswa dalam diskusi.

(Nana Sudjana, 1992 : 113)

Jika ada aktivitas teramati pada seorang siswa maka siswa tersebut diberi skor 1 , jika tidak diberi skor 0. Skor aktivitas diperoleh dengan menjumlahkan skor yang didapat oleh siswa yang bersangkutan untuk setiap aktivitas.

b. Tes akhir

Instrumen penelitian yang digunakan untuk mengetahui tingkat prestasi belajar siswa dengan menggunakan tes tulis.

\section{Teknik Pengumpulan Data}

a. Data hasil belajar siswa yang diperoleh dengan cara memberikan evaluasi belajar pada meteri pokok lingkaran setelah akhir dari setiap siklus pembelajaran berlangsung. 
b. Data tentang situasi belajar didapat dari lembar observasi yang diberikan kepada siswa dan guru.

\section{Teknik Analisis Data dan Kriteria Keberhasilan}

Data yang diperoleh dari hasil penelitian tindakan kelas ini dianalisa denga cara sebagai berikut:

a. Menghitung rata-rata kelas digunakan rumus:

$M e=\frac{\sum x i}{n}$

Keterangan:

Me: Mean (rata-rata hasil belajar siswa)

$\sum x i$ : jumlah nilai yang diperoleh siswa

$n$ : banyaknya siswa yang ikut tes

Untuk mengetahui hasil belajar siswa, analisis secara deskriptif yaitu menentukan nilai ratarata hasil tes. Dikatakan berhasil dalam menguasai konsep yang disajikan apabila mencapai rata-rata kels lebih dari 75 .

b. Ketuntasan individu, setiap siswa dal proses belajar mengajar dikatakam tuntas secara individu apabila siswa mampu memperoleh nilai lebih dari atau sama dengan 75 .

c. Peningkatan prestasi belajar siswa dapat dilihat dari ketuntasan belajarnya yang dirumuskan sebagai berikut:

$K K=\frac{X}{Z} \times 100$

Keterangan :

$K K$ : ketuntasan klasikal

$Z$ : banyaknya siswa yang ikut test

$X$ : banyaknya siswa yang mendapatkan nilai lebih dari atau sama dengan 75 .

Sesuai dengan petunjuk teknik penilaian kelas dapat dikatakan tuntas secara klasikal terdapat prestasi pembelajaran yang disajikan bila ketuntasan klasikal mencapai 75\%.

Analisis data hasil observasi siswa yang dianalisa dengan cara sebagai berikut:

a. Data hasil observasi

Kegiatan observasi dilakukan untuk mengetahui aktivitas siswa dan guru. Instrumen yang digunakan untuk mengumpulkan data observasi yang berisikan deskriptif dari indikatoraktivitas siswa dan guru yang sudah diamati selama proses belajar mengajar berlangsung.

b. Data aktivitas belaajar siswa

Skor setiap individu tergantung banyak prilaku atau aktivitas yang dilakukan siswa dari jumlah deskriptor yang diamati.

Skor 5 diberi jika 4 deskriptor

Skor 4 diberi jika 3 deskriptor nampak

Skor 3 diberi jika 2 deskriptor nampak

Skor 2 diberi jika 1 deskriptor nampak

Skor 1 diberi jika tidak ada deskriptor nampak.

Keriterian aktivitas belajar siswa dapat dilihat pada Tabel 1 berikut ini:
Tabel 1. Kriteria Untuk Menentukan Aktivitas Belajar Siswa

\begin{tabular}{|c|c|c|}
\hline Interval & Nilai & Kategori \\
\hline$A s \geq M I+1,5$. SDI & As $\geq 4,5$ & Sangkat aktif \\
\hline $\begin{array}{l}\mathrm{MI}+0,5 . \mathrm{SDI} \leq \mathrm{As}< \\
\mathrm{MI}+1,5 . \mathrm{SDI}\end{array}$ & $\begin{array}{l}3,5 \leq \text { As }< \\
4,5\end{array}$ & Aktif \\
\hline $\begin{array}{l}\mathrm{MI}-0,5 . S D I \leq \mathrm{As} \\
<\mathrm{MI}+0,5 . \text { SDI }\end{array}$ & $\begin{array}{l}2,5 \leq 3,5 \\
<3 \mathrm{As}\end{array}$ & Cukup aktif \\
\hline $\begin{array}{l}\text { MI }-0,5 . \text { SDI } \leq \text { As }< \\
\text { MI- 0,5.SDI }\end{array}$ & $\begin{array}{l}1,5 \leq \text { As }< \\
2,5\end{array}$ & Kurang aktif \\
\hline As $<$ MI - 1,5.SDI & As $\leq 1,5$ & $\begin{array}{l}\text { Sangat } \\
\text { Kurang }\end{array}$ \\
\hline
\end{tabular}

(Suryadana, 2002: 20)

\section{Keriteria Keberhasilan}

Penelitian ini dikatakan berhasil apabila:

a. Prestasi belajar siswa meningkat apabila terjadi peningkatan ketuntasan belajar dari ketuntasan belajar siklus sebelumnya yang dilihat pada setiap akhir siklus. Proses belajar dikatakan tuntas secara klasikal apabila mencapai minimal $75 \%$ dari keseluruhan siswa.

b. Aktivitas siswa dikatakan meningkat, apabila terjadi peningkatan rata-rata skor dari ratarata skor siklus sebelumnya dan berkriteria aktif yang dilihat pada setiap siklusnya.

\section{HASIL DAN PEMBAHASAN}

\section{Dekripsi Hasil Penelitian}

Hasil penelitian ini diperoleh dari instrumen penelitian berupa tes hasil belajar dan hasil observasi pelasanaan pembelajaran matematika menggunakan Strategi pembelajaran Kreatif-Produktif pada siswa di kelas VIII SMP Negeri 1 Lambu. Pelajaran ini dilaksanakan dalam 2 (dua) siklus. Dari hasil observasi dan evaluasi diperolah data kualitatif berupa hasil belajar siswa pada akhir tiap-tiap siklus data tersebut selanjutnya dianalisis dengan menggunakan rumus yang telah digunakan sebelumnya.

Hasil penelitian yang diperoleh dalam penelitian ini adalah data mengenai hasil belajar siswa pada pokok bahasan operasi aljabar menggunakan soal tes esain dengan jumlah soal 5 butir pada setiap siklus yang terdiri dari tiga kali pertemuan pada masingmasing siklus. Pada etiap siklus dilakukan observasi mengenai kegiatan guru dan aktivitas siswa.

a. Hasil observasi

1) Hasil observasi aktivitas belajar siswa Hasil observasi diperoleh dari pengamatan yang dilakukan oleh guru sejawan (pendamping) dengan mengisi lembar observasi yang telah dipersiapkan oleh peneliti yang bertujuan untuk merekam jalannya proses belejar mengajar. Observasi terhadap aktifitas siswa dilakukan dengan mengamati prilaku siswa pada saat diskusi dalam kelompok dan 
proses belajar mengajar. Semua aktifitas yang nampak diberi tanda contreng dalam lembar observasi sesuai dengan deskriptor yang nampak.

Adapun hasil analisis data tersebut tertuang dalam Tabel 2 berikut ini.

Tabel 2. Data Hasil Observasi Aktivitas Siswa Siklus I

\begin{tabular}{cccc}
\hline Pertemuan & Jumlah & Rerata & Kategori \\
\hline I & 42 & 8,4 & Sangat Aktif \\
\hline II & 51 & 10,2 & Sangat Aktif \\
\hline
\end{tabular}

Berdasarkan hasil observasi kegiatan siswa dan analisa data ada kekurangankekurangan yang muncul pada siklus I yakni:

a) Sebagian siswa masih ada yang malu bertanya dan mengemukakan pendapat baik kepada teman kelompoknya maupun kepada guru.

b) Pada saat diskusi masih ada siswa yang tidak menangapi pendapat daritemannya.

c) Siswa masih kesulitan membuat kesimpulan dari hasil diskusinya.

d) Siswa mengerjakan pekerjaan lain pada saat proses belajar mengajarberlangsung.

2) Hasil observasi aktivitas guru

Hasil observasi diperoleh dari pengamatan yang dilakukan oleh guru matematika dengan mengisi lembar observasi yang telah dipersiapkan oleh peneliti yang bertujuan untuk merekam proses belajar smengajar. Observasi terhadap aktivitas guru dilakukan dengan mengamati prilaku guru pada saat proses belajar mengajar. Semua aktivitas guru yang nampak diberikan tanda rumput dalam observasi.Adapun hasil yang diperoleh dariobservasi terhadap guru terekam dalam Tabel 3berikut:

Tabel 3. Data Hasil Observasi Aktivitas Guru Siklus I

\begin{tabular}{cccc}
\hline Pertemuan & Jumlah & Rerata & Kategori \\
\hline I & 28 & 3,11 & Cukup Aktif \\
\hline II & 30 & 3,33 & Cukup Aktif \\
\hline
\end{tabular}

Berdasarkan hasil observasi kegiatan guru dan analisis data, ada kekurangan-kekurangan yang muncul pada siklus I yakni:

a) Guru menyampaikan materi telalu cepat

b) Guru terlihat mendominasi dalam proses pembelajaran

c) Guru masih kurang mengkaitkan materi dengan kehidupan sehari-hari

d) Guru masih kurang mengawasi siswa yang sedang mengerjakan kegiatan kelompok

e) Tidak memberikan umpan balik kepada siswa.
Tabel 4. Data Hasil Evaluasi Belajar Siswa Siklus I

\begin{tabular}{lc}
\hline \multicolumn{2}{c}{ Hasil evaluasi } \\
\hline Jumlah siswa seluruhnya & 32 \\
\hline Jumlah siswayang ikut tes & 28 \\
\hline Nilai tertinggi & 80 \\
\hline Nilai terendah & 54 \\
\hline Nilai rata-rata & 48,68 \\
\hline Jumlah siswa yang tuntas & 20 \\
\hline Jumlah siswa yang tidak & 8 \\
tuntas & $71,42 \%$ \\
\hline Presentasi ketuntasan
\end{tabular}

Dari Tabel 4diatas dapat dilihat dari indikator penelitian belum tercapai karena persentasi ketuntasan belajar belum mencapai standar minimal $75 \%$ dan pengolongan aktivitas belajar siswa dengan kategori cukup aktif. Hasil analisis secara rinci tentang data hassil evaluasi belajar siswa pada siklus I, pada pertemuan siklus berikutnya akan diberi bimbingan dan perhatian khusus dikelas ketika proses belajar mengajar berlangsung. Disamping itu juga guru melekukan upaya mendeteksi kendala-kendala yang dialami oleh siswa 8 orang tersebut. Karena penelitian pada siklus I belum mencapai ketuntasan belejar maka penelitian merencanakan tindakan perbaikan siklus II.

\section{3) Hasil observasi aktivitas siswa}

Hasil yang diperoleh dari pengamatan yang dilakukan oleh guru sejawa (pendamping) dengan mengisi lembar observasi yang telah dipersiapkan oleh peneliti yang bertujuan untuk merekam jalannya proses belajar mengajar. Observasi terhadap aktivitas siswa dilakukan dengan mengamati prilaku siswa pada saat diskusi dalam kelompok dan proses belajar mengajar. Semua aktivitas yang nampak di beri tanda contreng dalam lembar observasi sesuai dengan deskriptor yang muncul. Adapun hasil analisis data tersebut tertuang pada Tabel 5berikut ini:

Tabel 5. Data Hasil Observasi Aktivitas Siswa Siklus II

\begin{tabular}{cccc}
\hline Pertemuan & Jumlah & Rerata & Kategori \\
\hline I & 58 & 11,6 & Sangat aktif \\
\hline II & 77 & 15,4 & Sangat aktif \\
\hline
\end{tabular}

4) Data observasi kegiata guru

Hasil observasi diperoleh dari pengamatan yang dilakukan oleh guru matematika kelas VIII dengan mengisi lembar observasi yang telah dipersiapkan oleh peneliti yang bertujuan untuk merekam jalannya proses belajar mengajar. Adapun hasil yang diperoleh terangkum pada Tabel 6 dibawah ini: 
Tabel 6. Data Hasil Observasi Kegiatan Guru Siklus II

\begin{tabular}{cccc}
\hline \multirow{2}{*}{ Pertemuan } & \multicolumn{3}{c}{ Siklus I } \\
\cline { 2 - 4 } & Jumlah & Rerata & Kategori \\
\hline Pertemuan 1 & 32 & 3,55 & $\begin{array}{c}\text { Cukup } \\
\text { Aktif }\end{array}$ \\
\hline Pertemuan 2 & 31 & 3,44 & $\begin{array}{c}\text { Cukup } \\
\text { Aktif }\end{array}$ \\
\hline
\end{tabular}

Tabel 7. Data Hasil Evaluasi Belajar Siswa Siklus II

\begin{tabular}{lc}
\hline \multicolumn{2}{c}{ Hasil Evaluasi } \\
\hline Jumlah siswa seluruhnya & 32 \\
\hline Jumlah siswa yang ikut tes & 32 \\
\hline Nilai tertinggi & 85 \\
\hline Nilai terendah & 73 \\
\hline Nilai rata-rata & 64,34 \\
\hline Jumlah siswa yang tuntas & 25 \\
\hline Jumlah siswa yang tidak & 7 \\
\hline tuntas & $78,12 \%$ \\
\hline
\end{tabular}

Berdasarkan Tabel 7 diatas menunjukan bahwahasil tes belajar siswa pada siklus II mengalami peningkatan yaitu sebesar 78,12\% atau tuntas secara klasikal, karena ketuntasannya melebisi standar yang sudah ditetapkan yaitu 75\%. Pada siklus II ini terlihat ada peningkatan dari siklus sebelumnya karena sudah mengalami ketuntasan baik secara individu maupun secara klasikal yang diharapkan. Hal inimenandakan bahwa dengan menggunakan strategi pembelajar kreatif-produktif dapat meningkatkan belajar siswa.

\section{Pembahasan}

Berdasarkan hasil analisis data pada tiap-tiap siklus, terlihat bahwa hasil dari siklus I ke siklus II mengalami peningkatan. Pada pelaksanaan pembelajaran dan hasil analisis data siklus I, diperoleh nilai rata-rata siswa kelas VIII 48 dari 32 siswa dan yang tuntas sebanyak 20 orang atau ketuntasan belajar mencapai $71,42 \%$ dengan materi operasi aljabar. Hal ini belum mencapai ketuntasan balajar yang diharapkan yaitu $75 \%$ atau lebih dan kategori aktivitas siswa" kurang aktif ". Menurut hasil diskusi peneliti dengan observer dan setelah dilakukan refleksi, hal ini disebabkan larena kurangnya bimbingan dan arahan yang merata kepada kelompok maupun individu siswa pada saa mengerjakan LKS sehingga siswa belum tuntas atau kurang terdeteksi. Umtuk mengatasi hat tersebut, khusus pada siswa yang belum mencapai ketuntasan, peneliti mengadakan bimbingan belajar mengenai LKS yang belum dikuasai.

Karena ketuntasan belajar pada siklus I belum mencapai, maka pelaksanaan tindakan pada siklus II dengan perbaikan-perbaikan seperti yang disarankan oleh observer yang diharapkan lebih banyak melakukan pendekatan-pendekatan, bimbingan dan pengarahan khusus kepada siswa yang belum mencapai ketuntasan belajar. Pada tindakan siklus II guru harus lebih banyak memberikan umpan balik tentang materi yang dipresentasikan oleh masingmasing kelompok dengan harapan suasana belajar mengajar makin hidup, siswa makin bersemangat dan termotivasi.

Hasil analisis pada siklus II menunjukkan adanya peningkatan, ini terlihat dari presentase ketuntasan sebesar $78,12 \%$ dan terlihat mengalami peningkatan dibandingkan dengan siklus I yaitu sebesar 71,42\%, selain itu aktivitas siswa pada siklus II sudah sangat baik ini telihat dari antusias mereka pada saat proses kegiatan belajar mengajar berlangsung, karena siswa sudah terbiasa dengan metode pembelajaran yang diterapkan sehingga pada siklus II sudah dikatakan berhasil.

Berhasil tidaknya suatu pembelajaran di sekolah tidak terlepas dari komponen-komponen pembelajaran. Diantaranya siswa, guru, sarana, materi, dan pendekatan atau metode serta strategi yang digunakan untuk menyampaikan materi pembelajaran. Semua komponen tersebut satu sama lain memiliki hubungan yang erat. Suatu konsep yang disampaikan oleh guru akan mudah diterima apabila guru menggunakan metode pembelajaran yang tepat. Dengan demikian, siswa akan lebih aktif dan mengingat bahan pelajaran. Dibandingkan dengan metode ceramah yang masih berpusat pada guru serta kurangnya variasi dalam belajar akan membuat siswa kurang aktif dan kreatif dalam belajar. Hal itu yang menyebabkan rendahnya hasil belajar siswa. Jadi penerapan strategi pembelajaran kretifproduktif ini dapat meningkatkan nilai akademik siswa yang berhubungan dengan hasil belajar

\section{SIMPULAN DAN SARAN}

Berdasarkan hasil penelitian dan pembahasan diatas dapat disimpulkan bahwa "strategi pembelajara kreatif-produktif dapat meningkatkan hasil belajar matematika siswa kelas VIII SMP Negeri 1 Lambu". Hal ini dapat dilihat dari aktivitas siswa pada siklus I pertemuan pertama sebesar 8,4 dan pertemua ke dua 10, 2 tergolong aktif, dan pada siklus II pertemuan pertama 11,6 dan pertemuan ke dua 15,4 tergolong angat aktif sedangkan prestasi belajar pada siklus I dengan nilai rata-rata sebesar 48,68 dan pada siklus II sebesar 64,34. Ketuntasan klasikal pada siklus I sebesar $71,42 \%$ dan pada siklus II sebesar $78,12 \%$. Sehingga dari penjelasan di atas dapat disimpulkan bahwa penerapan strategi pembelajaran kreatif-produktif dapat meningkatkan aktivitas belajar siswa.

Adapun saran-saran yang disampaikan sehubungan dengan hasil penelitian ini adalah sebagai berikut: 
1. Guru diharapkan menerapkan strategi pembelajaran kreatif-produktif untuk menuntaskan hasil belajar dan meningkatkan aktivitas belajar siswa dalam pembelajaran matematika selanjutnya.

2. Bagi siswa diharapkan terlibat langsung dalam pembelajaran sehingga aktivitas belajar menjadi optimal dalam meningkatkan prestasi belajar.

3. Bagi mahasiswa yang ingin meneliti lebih lanjut diharapkan mencoba menerapkan strategi pembelajaran kreatif-produktif ini dengan mencermati kekurangan-kekurangannya.

\section{REFERENSI}

Arikunto, Suharsimi. (2008). Penelitian Tindakan Kelas. Jakarta: Bumi Aksara.

Aqib, Zainal. (2009). Penelitian Tindakan Sekolah. Bandung: Yrama Widya.

Fadrik Adi Fahrudin. (2017). Efektivitas Problem Based Learning Terhadap Kemampuan Berpikir Kreatif Mahasiswa Program Studi Tadris Matematika UIN Mataram. Jurnal Teori dan Aplikasi Matematika, 1(1), 41-48

Hamalik, Oemar. (2008).Kurikulum dan Pembelajaran.Jakarta: Bumi Aksara.

Hanafiah. (2010). Konsep Strategi Pembelajaran. Bandung: Refika Aditama.

Hendra Erik Rudyanto. (2014). Model Discovery Learning Dengan Pendekatan Saintifik Bermuatan Karakter Untuk Meningkatkan Kemampuan Berpikir Kreatif. Premiere Educantum, 4(1), 41-48

Johnson, Richard. (2007). Applied Multivariate Statistical Analysis.United States: Prentice Hall

Musfiroh, Takdiroh. (2003). Bermain Sambil Belajar dan Melatih Kecerdasan Anak. Jakarta: Bumi Angkasa

Pendawi Dwi Herdani, Novisita Ratu. (2018). Analisis Tingkat Kemampuan Berpikir Kreatif Matematis Siswa SMP Dalam Menyelesaikan Open - Ended Problem Pada Materi Bangun Datar Segi Empat. Jurnal Teori dan Aplikasi Matematika, 2(1), 9-16

Slameto. (2003). Belajar dan Faktor-Faktor yang Mempengaruhinya. Jakarta: PTRinekaCipta.

Sugiyono. (2013). Metode Penelitian Pendidikan (Pendekatan Kuantitatif, Kualitatif, dan R\&D). Bandung: Alfabeta

Sugiono Anas. (2009). Pengantar Statistik Pendidikan. Jakarta:Raja Grafika Persada

Sugiyono. (2009). Metode Penelitian Pendidikan. Bandung: Alfabeta.

Tatag Yuli Eko Siswono. (2007). Konstruksi Teoritik Tentang Tingkat Berpikir Kreatif Siswa Dalam Matematika. Jurusan Matematika FMIPA UNESA, 5(1), 1-10 